\title{
Integrating International Students into Tertiary Education Using Intercultural Peer-to-peer Training at Jacobs University Bremen, Germany
}

\author{
Nadine Binder, Margrit Schreier, Ulrich Kühnen, Karina Karolina Kedzior \\ Jacobs University Bremen, Germany \\ Correspondence: Ulrich Kühnen, Jacobs University Bremen, Germany. E-mail: u.kuehnen@ jacobs-university.de
}

Received: July 3, 2013 Accepted: July 22, 2013 Online Published: August 21, 2013

doi:10.11114/jets.v1i2.170

URL: http://dx.doi.org/10.11114/jets.v1i2.170

\begin{abstract}
Increasing internationalization of higher education raises the question of how well institutions prepare their students to integrate into and benefit from cultural diversity on any university campus. The aim of this study was to assess an intercultural peer-to-peer training at Jacobs University Bremen, Germany, that aims to facilitate the integration of incoming students into the multicultural environment of this international university. The individual experience of eight undergraduate students was explored using qualitative in-depth interviews. The results suggest that motivation to participate and satisfaction with the training were highest among students with some intercultural experience compared to students with extensive or little intercultural experience. All students supported the overall training format and the peer-trainer scheme. It seems that the training has adequately addressed the issues related to the general social life on the multicultural campus. However, it should focus more specifically on the learning model used and learning-related expectations at Jacobs University Bremen. In conclusion, the current study provides the first qualitative evaluation of an intercultural peer-to-peer training that could be utilized at other educational institutions in Germany and beyond as a method of linking culture-related issues to academic and social life of new students.
\end{abstract}

Keywords: international education; intercultural training; peer-training; multicultural campus

\section{Introduction}

Higher education is becoming increasingly internationalized. In 2009, more than 3.7 million tertiary students were enrolled outside their home country as compared to 0.8 million in 1975 (OECD, 2011, pp. 318, 320). UNESCO estimates predict that their number will rise even further to 7 million by 2020 (Altbach, Reisberg, \& Rumbley, 2009). Cultural diversity at universities can be enriching, allowing knowledge flow across national boundaries and enabling students to develop skills to succeed in a global work environment. However, educational institutions are often poorly prepared to assist their international students to settle into a new environment (Kuschel et al., 2007; Leask \& Carroll, 2011). Challenges commonly experienced by international students are language barriers, new cultural norms, an unfamiliar classroom culture, academic stress and pressure to succeed, lack of social support and the need to establish a new social network, perceived discrimination, and financial difficulties (Church, 1982; Myles \& Cheng, 2003; Smith \& Khawaja, 2011; Tung, 2011). As a consequence some students underperform academically or even drop out and return home. A recent study by the Higher Education Information System (HIS) Germany shows that the dropout rate for undergraduate foreign students is higher (46\%) than the average undergraduate dropout rate (28\%) in Germany (Heublein et al., 2012).

Germany ranks third in the most popular study-abroad destinations (OECD, 2011), but so far there have been only a few attempts at universities to develop cultural competence (Bosse, 2009). One such attempt is the intercultural peer-to-peer training offered to all new incoming students at Jacobs University Bremen, Germany. While educational integration is often assessed in typical contexts of international students entering a new host country (see e.g., Church, 1982; Ippolito, 2007; McKinlay, Pattison, \& Gross, 1996; Myles \& Cheng, 2003; Quintrell \& Westwood, 1994; Smith \& Khawaja, 2011; Tung, 2011; Westwood \& Barker, 1990), Jacobs University Bremen offers a multicultural environment for all students. Specifically, Jacobs University Bremen is a small (total 2012 enrollment of $N=1335$ students of which about $25 \%$ are German), private, English-speaking 
international university operating in Northern Germany since 2001. Its residential campus is home to students from over 110 nations who often have multicultural and multilinguistic backgrounds (for more information see: http://www.jacobs-university.de). According to the university motto, 'intercultural understanding is an integral part of life at Jacobs University Bremen that should be promoted to ensure that students, faculty and staff are well prepared to live and work together in a positive manner [...]' (Jacobs University Bremen, 2012).

When Jacobs University Bremen was opened in 2001, its founders believed that the cultural diversity of the student body would be beneficial for students and faculty and intercultural training was not considered to be necessary. This approach was based on the classic contact hypothesis (Allport, 1954; Brewer, 2003) suggesting that relations among various cultural groups on campus would improve over time due to the mere contact that living together in residential colleges brings about. However, mere physical proximity alone is insufficient and might even lead to adverse effects, if certain qualifying conditions are not met, such as equal status and superordinate goals (Brewer, 2003). This reasoning finally led to the development of a comprehensive peer-to-peer training program targeted at all incoming students which was based on a needs assessment and first conducted in 2005 (Kuschel et al., 2007).

In general, any intercultural training aims to raise awareness, sensitize individuals to cultural differences, and prepare them to deal effectively with those (Fischer, 2011). The mandatory eight-hour full-day training at Jacobs University Bremen aims to familiarize incoming students with the university's learning model, facilitate their start in the new multicultural environment, and provide them with skills to benefit from the intercultural experience on campus (Kuschel et al., 2007). In line with the multicultural background of many students, the training at Jacobs University Bremen utilizes the so-called 'culture-general approach' as opposed to a 'culture-specific approach' that offers information and behavioral guidelines for a specific culture only (Graf, 2004).

The intercultural training at Jacobs University Bremen is conducted in small groups of 10-15 students with a diverse range of culture of origin, gender, and study major. Each group is trained by a pair of peer-trainers from different cultural backgrounds who are senior students recruited voluntarily from the student body. Trainers are prepared for training in an intensive two-day Train-the-Trainer workshop which familiarizes them with contents and exercises and provides room to practice training skills (Kuschel et al., 2007). The format of training consists of a mixture of didactic/lecture and experiential approaches (Fischer, 2011; Graf, 2004). While the didactic or lecture approach considers cognitive understanding of a culture as a prerequisite for effective intercultural interaction, the experiential approach assumes that people learn best from own experiences (Graf, 2004).

Furthermore, the intercultural training at Jacobs University Bremen utilizes a peer-trainer scheme based on the assumption that peer-trainers have a better understanding of participants' concerns, can be credible role models, and provide continuous positive social influence. However, there is little research on peer-trainer schemes in international educational contexts. Positive effects of a peer-pairing program on both host and international students have been documented at the University of British Columbia (Quintrell \& Westwood, 1994; Westwood $\&$ Barker, 1990). Westwood and Barker (1990) found support for a positive relationship between participation in the peer-pairing program and academic success. While the follow-up study by Quintrell and Westwood (1994) could not replicate these effects, it demonstrated other positive effects such as a more rewarding study-abroad experience by international students as well as increased knowledge about intercultural communication and other countries by local students. Similarly, a peer-training program at U.S. high schools aiming to fight prejudice and bigotry received positive feedback from trainers, high-school students, and staff (Tiven, 2001).

Though there has been little research on peer-trainer schemes in international educational contexts, some studies have been conducted on peer-mentoring in university settings in general. Such mentoring programs usually involve older students who act as mentors for incoming students helping them to integrate into the new study environment and making social contacts as well as offering assistance with study-related problems and concerns (Husband \& Jacobs, 2009). Peer-mentoring programs mainly aim at easing the transition to higher education, improving academic performance, and thereby retaining students and reducing drop-out rates (Fox \& Stevenson, 2010; Glaser, Hall, \& Halperin, 2006; Husband \& Jacobs, 2009). While the intercultural peer-training at Jacobs University Bremen includes such aims, it also explicitly seeks to prepare students for living and studying in an international environment. Research on peer-mentoring schemes has demonstrated their effectiveness in promoting social interaction and integration, creating supportive learning communities, reducing anxiety, and increasing student engagement (Calder, 2004; Husband \& Jacobs, 2009). Furthermore, studies show that mentees achieve higher levels of academic performance than their non-participating counterparts (Fox \& Stevenson, 2010) and that those who frequently used peer-mentoring schemes are more likely to find the training helpful in adjusting to the teaching style, making social contacts, accessing university services, and becoming part of the 
university community (Glaser et al., 2006). Some of these case studies also document positive effects for mentors themselves, such as improved communication and interpersonal skills as well as increased self-confidence (Glaser et al., 2006; Husband \& Jacobs, 2009). Yet, evaluations of various peer-mentoring programs in the UK and Australia also point to potential problems such as stress for mentors, personality mismatches, lack of mutually shared expectations and objectives, or absenteeism of mentees (Glaser et al., 2006; Husband \& Jacobs, 2009). These problems underline the importance of a thorough selection and preparation process and of clear communication about the program's objectives. This applies to intercultural peer-training as much as to peer-mentoring programs.

The idea to involve second and third year students as trainers for new students might be of particular interest for other educational institutions for several reasons. Firstly, rather than teaching the potential difficulties and challenges of the acculturation processes in an abstract and impersonal way, the senior students can convey their own experience from the previous years. Thus, this way of teaching is likely to be particularly authentic and lively. Secondly, being involved as a peer-trainer may also be an important learning experience in disseminating knowledge for the senior students. Thirdly, involving older student generations in the intercultural training of new students is an obviously efficient (and relatively inexpensive) way of knowledge transfer from one student generation to the next. At the same time, the critical question then is: Does it work? Do new students benefit from this kind of training as much as intended? The current research was conducted to partially address these questions.

While during pilot evaluation Kuschel et al. (2007) reported that the intercultural training concept at Jacobs University Bremen received positive feedback from both participants and peer-trainers, this feedback was collected in an unsystematic fashion: Specifically, immediately after the training, the participants filled out short evaluation forms in which they were asked to indicate what they liked and disliked about the training. It can be assumed that such an evaluation is primarily based on how the students felt during the training and how much fun the exercises were. However, the actual goal of this training is to provide long-term benefits to participants in particular during their first semester at this university. Thus, whether this purpose was fulfilled or not cannot be assessed at the end of training but only after the first semester is over. Therefore, the aim of the current study was to systematically and qualitatively assess the intercultural peer-to-peer training at Jacobs University Bremen in order to better understand how the training is perceived by participating students. The qualitative approach was chosen because it allows a more in-depth exploration of the experience of a smaller sample of students that could be used as a starting point for a larger-scale follow-up study. The individual experience of eight undergraduate students was explored using qualitative in-depth interviews that addressed expectations and motivations prior to the training, the overall training experience and the performance of peer-trainers. These interviews were conducted in the beginning of the second semester of study so that the participants were able to reflect upon and comment on the long-term effects of the training during their first semester of study.

\section{Methods}

\subsection{Participants and Sampling}

To systematically explore the experience of participants in the intercultural peer-to-peer training at Jacobs University Bremen, a heterogeneous purposive sample was required (Boehnke, Lietz, Schreier, \& Wilhelm, 2011; Jansen, 2010). The study population consisted of first-year, undergraduate students, who had participated in the intercultural training in late August 2011 (beginning of first semester of study) and were interviewed in late February/early March 2012 (beginning of second semester).

To ensure the heterogeneity of the sample, a set of factors was identified that was likely to cause variation in the students' experience of the training: namely cultural background, previous intercultural experience such as living or studying abroad, and general attitude towards the training. Composing a small sample that differs across a set of relevant factors requires prior knowledge about the participants' values on these factors. Therefore, participant selection took place in three steps. In a first step, potential participants were recruited using the internal e-mail system at Jacobs University Bremen and from a first-year statistics course by word of mouth. In a second step, interested students were sent a pretest which included questions on the above factors. In a final step, eight participants who differed on the combinations of these factors were selected to participate in the current study. This procedure corresponds to the small-scale implementation of an explanatory mixed methods design where a first quantitative strand is used towards the selection of participants in the second qualitative strand (Creswell \& Plano Clark, 2011, ch. 3). 
Even though non-representative, the final sample thus consisted of eight first-year undergraduate students $(N=5$ female) with different cultural backgrounds and with a broad range of self-rated opinions towards the training (see the Results section). All participants received course credits for participation in this study.

\subsection{Data Collection}

Prior to data collection, all participants gave a written informed consent to participate in this study. Qualitative semi-structured interviews (conducted in English by NB and audio-recorded with permission of the participants) took place in residential colleges on the campus of Jacobs University Bremen and lasted for a mean of 22 minutes each (excluding introduction and debriefing). An interview guide was developed based on feedback from the Counseling and Intercultural Services ${ }^{1}$ at Jacobs University Bremen, author's (NB) experience as both a participant and a peer-trainer at the intercultural training, and the relevant literature as discussed above.

A pilot test of the interview guide suggested that all questions were understandable. The final interview guide was organized around the three major topic sections: (1) participant's personal background, expectations and motivation prior to the intercultural training, (2) the peer-trainer scheme, (3) the intercultural training structure (methods, subjective experience, aims). Throughout the interview guide, elements of episodic interviewing were used to evoke narrative episodes and facilitate recall of the intercultural training (Flick, 2000).

\subsection{Data Analysis}

A full verbal transcription of all interviews was done by NB. Data analysis consisted of two rounds of coding. In the first round, open, line-by-line coding was done to become familiar with the data and avoid imposing own preconceptions (Gibbs, 2007). In a second step, selective coding was done to condense open codes into conceptual categories. Selective coding included a combination of deductive and inductive coding. Following a deductive, concept-driven approach, broader categories were derived from the interview guide. At the same time, subcategories were drawn from the open codes using an inductive, data-driven approach. Selective codes and their definitions were collected in a list of codes (for list of codes, see Appendix Table A) and arranged in a hierarchy. In a final step, tables were created for all topic areas relevant to the aim of the study to further systematize the data and allow for cross-case comparison.

\section{Results}

Percentages reported in this section may exceed $100 \%$ because participants frequently commented on several aspects of training concurrently.

\subsection{Participants' Background and Expectations/Motivation Prior to the Intercultural Training}

The sample characteristics are summarized in Table 1.

Table 1. Sample Characteristics

\begin{tabular}{|c|c|c|c|c|c|}
\hline & $\begin{array}{c}\text { Cultural } \\
\text { background }\end{array}$ & $\begin{array}{c}\text { Subjective previous } \\
\text { intercultural experience }\end{array}$ & $\begin{array}{l}\text { Expectations before } \\
\text { training }\end{array}$ & $\begin{array}{l}\text { Motivation to } \\
\text { attend training }\end{array}$ & $\begin{array}{l}\text { Rating of } \\
\text { training }\end{array}$ \\
\hline 1 & $\begin{array}{l}\text { Multicultural; } \\
\text { Born in Ethiopia; } \\
\text { Feels German }\end{array}$ & $\begin{array}{l}\text { A lot of experience } \\
\text { Born in Ethiopia; lived in the } \\
\text { Netherlands, Germany, } \\
\text { Tunisia; International School } \\
\text { Tunisia }\end{array}$ & $\begin{array}{l}\text { Redundant due to } \\
\text { intercultural } \\
\text { experience }\end{array}$ & $\frac{\text { Low }}{\text { Skeptical }}$ & $1 / 5$ \\
\hline 2 & Norwegian & $\begin{array}{c}\text { A lot of experience } \\
\text { International School USA }\end{array}$ & $\begin{array}{l}\text { Redundant due to } \\
\text { intercultural } \\
\text { experience; } \\
\text { opportunity for } \\
\text { socializing }\end{array}$ & $\begin{array}{l}\text { Medium } \\
\text { Open-minded; } \\
\text { Intercultural } \\
\text { training is } \\
\text { always useful }\end{array}$ & $4 / 5$ \\
\hline 3 & $\begin{array}{l}\text { Born in Philippines; } \\
\text { Feels U.S. } \\
\text { American } \\
\end{array}$ & $\begin{array}{c}\text { A lot of experience } \\
\text { Moved to LA (USA) seven } \\
\text { years ago }\end{array}$ & $\begin{array}{l}\text { Redundant due to } \\
\text { intercultural } \\
\text { experience }\end{array}$ & $\underline{\text { Low }}$ & $3 / 5$ \\
\hline 4 & Honduran & Some experience & Receive advice & High & $5 / 5$ \\
\hline
\end{tabular}

\footnotetext{
${ }^{1}$ Counseling and Intercultural Services are responsible for the selection of peer-trainers, conducting the Train-the-Trainer workshop, and the intercultural peer-training. They also offer psychological counseling, life coaching, mediation, support groups, workshops, and awareness campaigns.
} 


\begin{tabular}{|c|c|c|c|c|c|}
\hline & & $\begin{array}{l}\text { International School with low } \\
\text { diversity }\end{array}$ & & $\begin{array}{c}\text { Nervous and } \\
\text { excited }\end{array}$ & \\
\hline 5 & German & $\begin{array}{c}\text { Some experience } \\
\text { Lived in the Netherlands, } \\
\text { France, Belgium; } \\
\text { International School Belgium }\end{array}$ & $\begin{array}{c}\text { Opportunity for } \\
\text { socializing; receive } \\
\text { advice }\end{array}$ & High & $4 / 5$ \\
\hline 6 & German & $\begin{array}{c}\text { Some experience } \\
\text { Lived in New Zealand (half a } \\
\text { year) }\end{array}$ & $\begin{array}{l}\text { No specific } \\
\text { expectations }\end{array}$ & High & $4 / 5$ \\
\hline 7 & Russian & $\begin{array}{c}\text { Limited experience } \\
\text { Involved with international } \\
\text { students in hometown }\end{array}$ & $\begin{array}{c}\text { Opportunity for } \\
\text { socializing; receive } \\
\text { advice }\end{array}$ & Medium & $3 / 5$ \\
\hline 8 & $\begin{array}{c}\text { Egyptian-American; } \\
\text { Bicultural }\end{array}$ & $\begin{array}{c}\text { A lot of experience } \\
\text { Lived in Egypt and USA; } \\
\text { German School Egypt; } \\
\text { Involved in international } \\
\text { camps }\end{array}$ & $\begin{array}{l}\text { Feeling familiar } \\
\text { with content; } \\
\text { emphasis on } \\
\text { open-mindedness; } \\
\text { learning about } \\
\text { different } \\
\text { perspectives }\end{array}$ & High & $3 / 5$ \\
\hline
\end{tabular}

According to results shown in Table 1, the sample was diverse in cultural backgrounds including monocultural participants from Norway, Honduras, Germany, and Russia, and students with multicultural backgrounds such as Filipino-American, Egyptian-American, and Ethiopian-German. Participants also differed in their subjective previous intercultural experience which ranged from limited $(12 \%)$ to some $(38 \%)$ and extensive $(50 \%)$. It appears that such a prior experience was related to both the motivation to attend the training and how the participants rated the training in general. Specifically, all those with some intercultural experience had a high motivation to attend the training and also rated the training the highest with scores of 4-5/5 (mean rating of 4/5). In contrast, the results from the group with extensive intercultural experience are heterogeneous. Particularly students who experienced multicultural educational environments prior to enrolling at Jacobs University Bremen were skeptical about the training as illustrated by the following quote:

'[...] personally I heard quite a lot of people, I guess mostly people who come from international school like myself found it [the training] to be redundant because that's basically what I have been doing the last two years $[\ldots]$ '.

Consequently, half of the students with extensive intercultural experience had low motivation to attend the training. However, regardless of their extensive experience, the other half still had either medium or high motivation. The rating of the training in this group of students ranged between 1-4/5 (mean rating of 3/5). Finally, it is difficult to make any general statements about the group with limited intercultural experience because it consisted of only one student who had a medium motivation and rated the training with $3 / 5$.

In summary, it appears that students with some intercultural experience were most motivated to attend the training and also rated it highest compared to those with limited or extensive experience. Such students with some intercultural experience are likely to be prevalent at other traditional universities (with domestic and foreign students) in Germany and elsewhere and seem to be the most appropriate audience for the training. The appropriate marketing strategy might also increase the motivation to attend the training among students with extensive and little intercultural experience in the multicultural environment at Jacobs University Bremen.

\subsection{Peer-trainer Scheme}

All participants were in favor of the peer-trainer scheme as the following quote exemplifies:

'I thought this is actually pretty neat because they could talk about own experiences and afterwards, you could also go and talk to them, like you had a reference person. So that is maybe nicer than a professional cultural trainer because that is like you really believe what these people tell you because they have experienced it themselves.'

Participants mentioned a number of positive aspects of peer-training, such as shared experience and understanding of participants' concerns (75\%), comfortable atmosphere $(62 \%)$, higher credibility than non-student trainers $(25 \%)$, increased applicability to the specific setting which facilitates adjustment (25\%), greater ease to relate to the trainers and the training (12\%), and interaction with trainers and peers (12\%). However, some identified the small age gap as a problem resulting in reduced authority and respect for trainers 
(25\%). Participants' comments regarding their peer-trainers revealed that all perceived their trainers to be competent to deliver the training and the majority also found them approachable after the training (75\%). Trainers were further positively described as committed (38\%), friendly and open (25\%), and serving as a reference person $(12 \%)$ or a role model $(12 \%)$ after the training. Only two participants criticized the trainers as not approachable (25\%) and lacking enthusiasm, interest and motivation (25\%). These results support the benefits of using peer-trainers in the context of intercultural training. The problems resulting from a small age-gap could be solved by using graduate students as peer-trainers. However, due to a campus design of the university, the undergraduate peer-trainers are likely to live on campus in a close vicinity to their trainees and thus are more aware of intercultural issues among the undergraduate students. In contrast, graduate students often live outside of the campus and may have prior little intercultural experience themselves. Thus, rather than increasing the age-gap it would be important to equip the trainers with pedagogic methods, possibly similar to those used in senior secondary schools, on how to deal with audience that is likely to be similar in age to the instructors. These results also highlight the importance of choosing appropriate new trainers (who should be approachable, enthusiastic, motivated) and adequately preparing them for delivering the training.

\subsection{Methods Used in the Intercultural Training}

Participants reported that all trainers combined lecture and experiential methods of teaching. This combination was also preferred by the majority of participants $(75 \%)$, but some participants favored a focus on experiential methods (38\%):

'I think, the combination is best. If I had to decide, then definitely the exercises.'

Some participants (38\%) remarked that lectures tended to be boring even though they appreciated being provided with information to work with during exercises (12\%). In contrast, experiential methods received mainly positive feedback in terms of learning by doing (50\%), fostering discussion (12\%), being stimulating (12\%), and more effective especially if the purpose of the exercise is unknown (12\%).

These results suggest that in general the combination of lecture and experiential methods utilized during the intercultural training at Jacobs University Bremen is perceived positively by participants and allows meeting the different preferences as found in this sample. Yet, the findings also point toward areas for improvement such as reducing the length of lectures for the sake of having more practical exercises.

\subsection{Intercultural Training Experience and Its Aims}

The main two aims of the intercultural training were to facilitate learning skills and social-life skills in the multicultural environment at Jacobs University Bremen. In agreement with these aims, the participants listed the following positive aspects of the intercultural training: preparation for life at Jacobs University Bremen (50\%), preparation for satisfactory learning (38\%), discussing real-life situations (25\%), and interactivity (12\%).

In terms of facilitating learning skills the participants reported discussing different classroom cultures (38\%), the role of active participation in classes (38\%), being critical (25\%), different learning models (12\%), appropriate classroom behavior (12\%), and the role of academic transdisciplinarity (12\%). However, some participants felt that the learning model at Jacobs University Bremen was not sufficiently covered (38\%) and only one participant explicitly mentioned that the training was helpful in adjusting to the learning model used at Jacobs University Bremen (12\%). The following quotes illustrate this criticism:

'They might have said something [about the learning model], but I don't think I would remember. But just based on how it was set up, I think participation was emphasized, but I don't remember any concrete mentioning.'

'I mean they definitely mentioned that compared, there are a lot of societies [...] where you in the classroom, really it is a lecture, like you sit there and the teacher just talks and talks and talks and in the end you are not allowed to disagree, you are not allowed to raise your hand, you are not allowed to do anything, like it is not that you don't have to, it is really that you can't. So, they definitely stressed that this is not the case here and that they are very open to discussions and stuff.'

In terms of the general social-life skills, participants reported discussing the awareness of cultural differences $(25 \%)$, ways of coping with cultural differences (12\%), tolerance (12\%), awareness of appropriate behavior (12\%), and differing degrees of cultural awareness among people (12\%). One participant stated:

'I think it was really real, like the situations that we were exposed to, like the situations with our roommates or people speaking other languages in the servery [a dining hall], like those were situations that really prepared you because it really happened. So it was really nice to already be like 
psychologically prepared that you might encounter these situations and know that everyone knows it and that it is ok to face them $[\ldots]$.

Furthermore, some participants felt that the training facilitated their integration into a multicultural environment $(38 \%)$ as illustrated by the following quote:

'I would say it did a really good job in that [facilitating integration]. [...] Maybe because we have different customs and the way we live in our rooms and just to be able to know that you can tell the person you are living with and express to them in a honest way what you feel [...]'

Finally, participants felt they had developed their self-reflection skills (50\%), perspective-taking abilities (12\%), basic communication skills such as patience with accents $(12 \%)$ or the ability to communicate own cultural beliefs to others $(12 \%)$. Yet, some expressed doubts that skills to benefit from the intercultural experience can be taught in such a short period of time $(25 \%)$ or even felt that no skills were taught $(12 \%)$. However, more participants $(50 \%)$ considered the intercultural training to be sufficient with no need for follow-up workshops or activities while others (38\%) favored the idea of follow-ups.

The general limitations of the training included not having learned any specific behavioral strategies for intercultural encounters $(25 \%)$, the training having a limited impact on student integration $(25 \%)$, the lack of culture-specific information (12\%), and too little reflection (12\%).

In sum, most participants reported that the training met its two aims- facilitating learning and social life at Jacobs University Bremen. The quotes confirm that the students particularly benefitted from suggestions and exercises on how to deal with cultural differences in everyday life on campus. While the learning differences related to culture were also addressed in general terms, it appears that the training should focus more specifically on the learning model used at Jacobs University Bremen. Another improvement proposed by the participants would be to utilize some culture-specific information from Country Information Days ${ }^{2}$ to further facilitate the integration of students to both academic and social life using specific examples of some common cultures on campus.

\section{Discussion}

This study aimed at qualitatively exploring students' subjective experience of the intercultural training at Jacobs University Bremen. There was an overall support for the general format of the training, especially in terms of use of peer-trainers and training methods. The students who were most motivated to attend the training and also rated it the highest had some intercultural experience already and probably saw the training as a tool to further extend their knowledge of other cultures. Finally, the training adequately addressed the social-life aspects of living on an intercultural campus, while the specific learning model used at Jacobs University Bremen would need to be explained in more length in the future.

\subsection{Participants' Background and Expectations/Motivation Prior to the Intercultural Training}

Though the redundancy perception found among some participants with extensive or little intercultural experience does not necessarily imply a negative training experience per se, it might decrease open-mindedness towards the training which has been found to be an important moderator of training effectiveness (Fischer, 2011). Decreased effectiveness might confirm the initial expectation of redundancy and lead to a further spread of this idea among students. This can in turn reduce open-mindedness and might also account for non-attendance. To disrupt this circle, the intercultural training should be advertised in such a way that it becomes more attractive to all students regardless of their prior intercultural experience to increase their willingness and motivation to participate in the training.

\subsection{Peer-trainer Scheme}

The peer-trainer scheme is at the core of the current study as only little research exists on similar approaches in other international educational settings. Results confirmed a number of benefits associated with the use of peer-trainers such as shared experience, credibility, authentic advice, and obtaining a long-term role model. However, findings also suggest that peer-trainers' skills and performance are crucial moderators of training experience. This underlines the importance of thorough preparation during the Train-the-Trainer workshop. Furthermore, it might be advisable to match trainer pairs according to skills, so that they can balance out each other's weaknesses. In support of this idea, one participant remarked that

\footnotetext{
${ }^{2}$ Country Information Days are organized by Jacobs University students who present their home country or region in an evening program open for everyone to attend. Country presentations include information, role-plays, traditional music and dance, and also local cuisine.
} 
'of course you had different people and one of them was more the facilitator one and the other person was less, [...], but I don't think that matters a lot, [...], it's important to have at least one who is really good at the facilitating part.'

\subsection{Methods Used in the Intercultural Training}

The combination of lecture and experiential methods across training groups is in line with evidence suggesting that a combination of methods contributes to effective teaching (Fischer, 2011). Participants evaluated experiential methods more favorably than lectures, supporting the findings of others (Graf, 2004; Pruegger \& Rogers, 1994). The lecture method was primarily criticized for being boring. This could potentially be improved by using a variety of media (Bhawuk \& Brislin, 2000). Although peer-trainers are provided with different materials including videos and slideshows (Kuschel et al., 2007), usage might differ across groups. Therefore, peer-trainers should be alerted to this issue and shown how to successfully integrate lectures into their training schedule during their preparation workshops.

\subsection{Intercultural Training Experience and Aims}

Most participants had a positive training experience in terms of feeling better prepared for living and studying in a multicultural environment and socializing with peers which is in line with the overall aims of this training. Participants positively remarked on the applicability of training contents to Jacobs University life, a feature that was intended in the development of the intercultural training (Kuschel et al., 2007). One problematic aspect of the training also emerged, namely that some participants did not clearly understand the connection between culture and academic performance. Thus, the influence of culture on learning beliefs and classroom culture at Jacobs University Bremen should be made clearer during the intercultural training. Some participants criticized a lack of learning culture-specific behavioral guidelines. However, teaching stereotypical dos and don'ts runs the risk of promoting a view of cultural groups as homogeneous and should be treated with caution (McKinlay et al., 1996). Furthermore, half of the participants felt to have developed their self-reflection skills, which Kuschel et al. (2007) consider to be one of the crucial meta-competencies needed to successfully live and work in a multicultural environment. Yet, doubts about the ability to develop skills within the short training period might be warranted. In particular, behavioral competencies seem to be hard to teach in short training sessions as participants might struggle to apply behaviors from the training to real-life situations (Fischer, 2011). Therefore, one aim of the training should be to make the participants aware of their individual needs and weaknesses which can then be addressed individually in the series of voluntary workshops on culture, academic, and career-oriented topics already offered at Jacobs University Bremen.

\subsection{Strengths and Limitations of the Study}

The strength of the current study is the systematic procedure that was implemented throughout. The use of a semi-structured interview guide, pilot-testing of the guide, audio-taping and literal transcription of interviews all contributed to this systematic approach (Flick, 2000). Open coding facilitated openness to participants' original wording and limited the risk of imposing own preconceptions and motives.

One limitation of the study is that interviews were conducted six months after participation in the intercultural training. On the one hand, this was done on purpose so that the participants were able to reflect about how much the training had helped them to adapt to the new environment during their first semester. On the other hand though, this time delay between the training and the interview might have contributed to participants not being able to accurately recall their experiences during the training. To address this limitation, episodic interviewing was used. Furthermore, an inherent limitation of qualitative research is the limited generalizability of results due to the small sample size used in this study. However, the aim of the current study was to explore perceptions of the training in a selected group of students rather than in a large sample in order to first identify important areas of focus for a future more representative evaluation of this training. In general, the current study can serve as an exploratory starting point for a larger, representative investigation that should ideally be conducted longitudinally to assess participants' and trainers' experience prior, directly after, and some-time after the intercultural training (possibly up to graduation). Such a study could employ a mixed-methods approach to account for individual experience and allow for generalizability. It should also aim to investigate the experiences of peer-trainers.

\section{Conclusion}

According to eight students interviewed six months after the intercultural peer-training, it appears that such training is an effective and comparatively low-cost way of introducing culture-related issues to new students at Jacobs University Bremen. The students particularly praised the role of peer-trainers in explaining the 
intercultural issues related to social life and academic performance at this university, thus supporting the use of a peer-trainer scheme. Yet, the study also discovered areas for further improvement. The appropriate advertisement and the use of various teaching methods could further improve the effectiveness of the training, particularly in terms of emphasizing the role of culture on academic performance. The role of teaching methods and use of a variety of media, as factors influencing participants' satisfaction with the training, point to the importance of carefully selecting and training the peer-trainers. While this adds to the complexity and the costs involved in the implementation of peer-training, these are nevertheless negligible compared to the costs associated with students dropping out before completing their studies. This particular form of peer-training thus lends itself to being adopted and utilized at other educational institutions in Germany and beyond as a comparatively easy and cost-effective way to reduce the drop-out rates of international students from education outside of their home country. Specifically, the peer-trainer scheme can be utilized elsewhere by using context-specific examples from personal experience of the peer-trainers and thus facilitate the integration of all incoming students into their new educational institution.

\section{Acknowledgements}

The authors wish to thank the Counseling and Intercultural Services at Jacobs University Bremen, Germany, for their valuable advice.

\section{References}

Allport, G. (1964). The nature of prejudice. Cambridge, MA: Perseus Books.

Altbach, P. G., Reisberg, L., \& Rumbley, L. E. (2009). Trends in global higher education: Tracking an academic revolution. Executive summary. Paris: UNESCO. Retrieved from http://unesdoc.unesco.org/images/0018/001831/183168e.pdf

Bhawuk, D. P. S., \& Brislin, R. W. (2000). Cross-cultural training: A review. Applied Psychology: An International Review, 49(1), 162-191.

Boehnke, K., Lietz, P., Schreier, M. \& Wilhelm, A. (2011). Sampling: the selection of cases for culturally comparative psychological research. In D. Matsumoto, \& F. van de Vijver (eds.), Cross-cultural research methods in psychology (pp. 101-129). Cambridge: Cambrige University Press.

Bosse, E. (2009). Intercultural training and development at Hildesheim University, Germany. Intercultural Education, 20(5), 485-489.

Brewer, M. B. (2003). Intergroup relations ( $2^{\text {nd }}$ ed.). Buckingham, UK: Open University Press.

Calder, A. (2004). Peer interaction in the transition process. Journal of the Australia and New Zealand Student Services Association, 23, 4-16.

Church, A. T. (1982). Sojourner adjustment. Psychological Bulletin, 91(3), 540-572. http://dx.doi.org/10.1037/0033-2909.91.3.540

Creswell, J. W. \& Plano Clark, V. (2011). Designing and conducting mixed methods research (2 $2^{\text {nd }}$ ed.). Thousand Oaks, CA: Sage.

Fischer, R. (2011). Cross-cultural training effects on cultural essentialism beliefs and cultural intelligence. $\begin{array}{lllll}\text { International Journal of Intercultural } & \text { Relations, } & 35(6), & \text { 767-775. }\end{array}$ http://dx.doi.org/10.1016/j.ijintrel.2011.08.005

Flick, U. (2000). Episodic interviewing. In M. W. Bauer, \& G. Gaskell (Eds.), Qualitative researching with text, image and sound. A practical handbook (pp. 75-92). London: Sage Publications.

Fox, A., \& Stevenson, L. (2010). Peer-mentoring undergraduate accounting students: The influence on approaches to learning and academic performance. Active Higher Learning in Higher Education, 11(2), $145-156$.

Gibbs, G. (2007). Analyzing qualitative data: Vol. 6. The SAGE Qualitative Research Kit. London: SAGE.

Glaser, N., Hall, R., \& Halperin, S. (2006). Students supporting students: The effects of peer mentoring on the experiences of first year university students. Journal of the Australia and New Zealand Student Services Association, 27, 4-17.

Graf, A. (2004). Assessing intercultural training designs. Journal of European Industrial Design, 28(2), 199-214.

Heublein, U., Richter, J., Schmelzer, R., \& Sommer, D. (2012). Die Entwicklung der Schwund- und Studienabbruchquoten an den deutschen Hochschulen. Statistische Berechnungen auf der Basis des 
Absolventenjahrgangs 2010. Forum Hochschule, 3/2012. Hannover: HIS. Retrieved from http://www.his.de/pdf/pub_fh/fh-201203.pdf

Husband, P.A., \& Jacobs, P.A. (2009). Peer mentoring in Higher Education: A review of the current literature and recommendations for implementation of mentoring schemes. The Plymouth Student Scientist, 2(1), 228-241.

Ippolito, K. (2007). Promoting intercultural learning in a multicultural university: Ideals and realities. Teaching in Higher Education, 12(5), 749-763. http://dx.doi.org/10.1080/13562510701596356

Jacobs University Bremen (2012). Intercultural affairs. Retrieved from http://www.jacobs-university.de/intercultural-affairs

Jansen, H. (2010). The Logic of Qualitative Survey Research and its Position in the Field of Social Research Methods [63 paragraphs]. Forum Qualitative Sozialforschung / Forum: Qualitative Social Research, 11(2), Art. 11, http://nbn-resolving.de/urn:nbn:de:0114-fqs1002110.

Kuschel, S., Özelsel, A., Haber, F., Jungermann, A., \& Kühnen, U. (2007). Interkulturelles Lernen an der Jacobs University Bremen: Das Erfolgsrezept Multiplikatoren-Schulung. [Intercultural learning at Jacobs University Bremen: Multiplier training as a formula of success] Internationalisierung, Vielfalt und Inklusion in Hochschulen, 1(4), 97-103.

Leask, B., \& Carroll, J. (2011). Moving beyond 'wishing and hoping': Internationalisation and student experiences of inclusion and engagement. Higher Education Research \& Development, 30(5), 647-659. http://dx.doi.org/10.1080/07294360.2011.598454

McKinlay, N. J., Pattison, H. M., \& Gross, H. (1996). An exploratory investigation of the effects of a cultural orientation programme on the psychological well-being of international university students. Higher Education, 31(3), 379-395. http://dx.doi.org/10.1007/BF00128438

Myles, J., \& Cheng, L. (2003). The social and cultural life of non-native English speaking international graduate students at a Canadian university. Journal of English for Academic Purposes, 2(3), 247-263. http://dx.doi.org/10.1016/S1475-1585(03)00028-6

OECD (2011). Education at a glance 2011: OECD indicators. OECD Publishing. http://dx.doi.org/10.1787/eag-2011-en

Pruegger, V. J., \& Rogers, T. B. (1994). Cross-cultural sensitivity training: Methods and assessment. $\begin{array}{lllll}\text { International Journal of Intercultural Relations, } & \text { 18(3), }\end{array}$ http://dx.doi.org/10.1016/0147-1767(94)90038-8

Quintrell, N., \& Westwood, M. (1994). The influence of a peer-pairing program on international students' first year experience and use of student services. Higher Education Research \& Development, 13(1), 49-58. http://dx.doi.org/10.1080/0729436940130105

Smith, R. A., \& Khawaja, N. G. (2011). A review of the acculturation experiences of international students. $\begin{array}{lllll}\text { International Journal of Intercultural } & \text { Relations, } & 35(6), & 699-713 .\end{array}$ http://dx.doi.org/10.1016/j.ijintrel.2011.08.004

Tiven, L. (2001). Student voices: The ADL's A WORLD OF DIFFERENCE Institute Peer Training program. In D. L. Schoem, \& S. Hurtado (Eds.), Intergroup dialogue: Deliberative democracy in school, college, community, and workplace (pp. 59-73). Michigan: University of Michigan Press.

Tung, W. (2011). Acculturative stress and help-seeking behaviors among international students. Home Health Care Management \& Practice, 23(5), 383-385. http://dx.doi.org/10.1177/1084822311405454

Westwood, M. J., \& Barker, M. (1990). Academic achievement and social adaptation among international students: A comparison groups study of the peer-pairing program. International Journal of Intercultural Relations, 14(2), 251-263. http://dx.doi.org/10.1016/0147-1767(90)90008-K 


\section{Appendix Table A. List of Codes}

\begin{tabular}{|c|c|c|c|}
\hline Label & Subcategories & Definition & Date \\
\hline $\mathrm{CB}$ & $\begin{array}{l}\text { Monocultural [culture XY] } \\
\text { Bicultural } \\
\text { Multicultural } \\
\text { Born in [country XY] } \\
\text { Feels [culture XY] }\end{array}$ & $\begin{array}{l}\text { Cultural background as described by the } \\
\text { participant. This can include comments } \\
\text { on own nationality, parents' nationalities, } \\
\text { place of birth, which culture he or she } \\
\text { feels belonging to and similar. }\end{array}$ & $24 / 03 / 2011$ \\
\hline CD JUB EX & $\begin{array}{l}\text { Number of nationalities } \\
\text { Roommate's nationality } \\
\text { Meeting people from previously unknown } \\
\text { countries } \\
\text { Different ways of communicating } \\
\text { Multicultural backgrounds of students } \\
\text { Different perceptions of time }\end{array}$ & $\begin{array}{l}\text { Examples of cultural diversity at Jacobs } \\
\text { University Bremen offered by the } \\
\text { participant. }\end{array}$ & $24 / 03 / 2011$ \\
\hline CD JUB EXP & $\begin{array}{l}\text { Facilitated by training } \\
\text { Little impact of training } \\
\text { Familiar } \\
\text { Interesting } \\
\text { Surprising } \\
\text { Enriching } \\
\text { Encourages self-reflection } \\
\text { Problem of clustering } \\
\text { Anxiety to not find friends } \\
\text { Feeling lost }\end{array}$ & $\begin{array}{l}\text { Any comment that the participant } \\
\text { makes on his or her experience of } \\
\text { cultural diversity at Jacobs University } \\
\text { Bremen. }\end{array}$ & $24 / 03 / 2011$ \\
\hline COP BEH & $\begin{array}{l}\text { Support networks } \\
\text { Friends } \\
\text { Family } \\
\text { Academic advisor } \\
\text { Counseling services on campus } \\
\text { Behavior } \\
\text { Sports } \\
\text { Confronting problems directly } \\
\end{array}$ & $\begin{array}{l}\text { Anything referring to the participant's } \\
\text { way of coping with difficulties such as } \\
\text { culture-related conflicts, academic } \\
\text { difficulties or personal problems. }\end{array}$ & $24 / 03 / 2011$ \\
\hline $\mathrm{CS}$ & $\begin{array}{l}\text { Aware } \\
\text { Made use of } \\
\text { Not used yet } \\
\text { Option for coping } \\
\text { No option for coping } \\
\text { Positive experience } \\
\end{array}$ & $\begin{array}{l}\text { Any comment made on Counseling and } \\
\text { Intercultural Services on campus. }\end{array}$ & $24 / 03 / 2011$ \\
\hline CULT & $\begin{array}{l}\text { Belief in culture's influence on cognition, } \\
\text { perception, behavior } \\
\text { Influences behavior } \\
\text { Influences attitudes } \\
\text { Influences decision-making } \\
\text { Source of miscommunication } \\
\text { Possible to neglect and adapt to environment } \\
\text { Interpersonal differences in influence }\end{array}$ & $\begin{array}{l}\text { Participant's understanding of culture, } \\
\text { culture's influence and related } \\
\text { comments. }\end{array}$ & $24 / 03 / 2011$ \\
\hline D PART & Major: XY & $\begin{array}{l}\text { Descriptives of participant, i.e. any } \\
\text { demographic information such as study } \\
\text { major. }\end{array}$ & $24 / 03 / 2011$ \\
\hline FOL-UP & $\begin{array}{l}\text { Not needed } \\
\text { Needed } \\
\text { More APS workshops } \\
\text { More voluntary workshops }\end{array}$ & $\begin{array}{l}\text { Attitude toward follow-up workshops to } \\
\text { the intercultural training. }\end{array}$ & $24 / 03 / 2011$ \\
\hline IC COMP & $\begin{array}{l}\text { Ability to appreciate cultural differences } \\
\text { Ability to interact with different cultures } \\
\text { Tolerance } \\
\text { Open-mindedness } \\
\text { Perspective-taking } \\
\text { Constant learning } \\
\text { Culture-specific knowledge }\end{array}$ & $\begin{array}{l}\text { Participant's understanding of } \\
\text { intercultural competence and his or her } \\
\text { own subjective definition. }\end{array}$ & $24 / 03 / 2011$ \\
\hline ICT ACT EX & $\begin{array}{l}\text { Freshmen Soup } \\
\text { BAFA BAFA } \\
\text { Critical Incidents } \\
\text { Classroom culture statements } \\
\text { What makes you [culture]? } \\
\text { Similarities and differences } \\
\end{array}$ & $\begin{array}{l}\text { Examples of activities done during the } \\
\text { intercultural training that the participant } \\
\text { can recall. }\end{array}$ & $24 / 03 / 2011$ \\
\hline
\end{tabular}




\begin{tabular}{|c|c|c|c|}
\hline & $\begin{array}{l}\text { Commonalities } \\
\text { Write something about yourself } \\
\text { What makes you unique? }\end{array}$ & & \\
\hline ICT CD JUB & $\begin{array}{l}\text { Awareness of cultural differences } \\
\text { Ways of coping with cultural differences } \\
\text { Tolerance } \\
\text { Awareness of appropriate behavior } \\
\text { Not learning behavioral strategies }\end{array}$ & $\begin{array}{l}\text { Comments on how the intercultural } \\
\text { training prepared students for their life } \\
\text { in a culturally diverse environment and } \\
\text { which related topics the training } \\
\text { addressed. }\end{array}$ & $24 / 03 / 2011$ \\
\hline ICT CONT & $\begin{array}{l}\frac{\text { Slogan }}{\text { No recall }} \\
\text { Ducks } \\
\text { Content } \\
\text { Openness to diversity } \\
\text { Iceberg model } \\
\text { Cultural differences }\end{array}$ & $\begin{array}{l}\text { Any content that the participant } \\
\text { remembers that has been covered in the } \\
\text { intercultural training. }\end{array}$ & $24 / 03 / 2011$ \\
\hline ICT EXP & General rating: $\mathrm{x} / 5$ & $\begin{array}{l}\text { General remarks on intercultural } \\
\text { training experience such as general } \\
\text { rating in the pretest. }\end{array}$ & $24 / 03 / 2011$ \\
\hline ICT EXP STUD & $\begin{array}{l}\text { Redundant } \\
\text { Boring } \\
\text { Positive }\end{array}$ & $\begin{array}{l}\text { Experience of intercultural training of } \\
\text { other students, i.e. references that the } \\
\text { participant makes to what other students } \\
\text { have told him or her about the } \\
\text { intercultural training. }\end{array}$ & $24 / 03 / 2011$ \\
\hline ICT GR MOT & $\begin{array}{l}\text { Low } \\
\text { Medium } \\
\text { High }\end{array}$ & $\begin{array}{l}\text { Participant's evaluation of the } \\
\text { motivation of the training group during } \\
\text { the intercultural training. }\end{array}$ & $24 / 03 / 2011$ \\
\hline ICT LM JUB & $\begin{array}{l}\text { Only briefly touched } \\
\text { Role of participation } \\
\text { Being critical } \\
\text { Different classroom cultures } \\
\text { Different learning models } \\
\text { Appropriate classroom behavior } \\
\text { Transdisciplinarity }\end{array}$ & $\begin{array}{l}\text { Comments on how the intercultural } \\
\text { training addressed the learning model at } \\
\text { Jacobs University Bremen and which } \\
\text { specific aspects have been addressed. }\end{array}$ & $24 / 03 / 2011$ \\
\hline ICT NEG & $\begin{array}{l}\text { Non-returners } \\
\text { Non-attendance } \\
\text { Boring } \\
\text { Too long } \\
\text { Too short } \\
\text { Lack of seriousness } \\
\text { Lack of culture-specific knowledge } \\
\text { No satisfactory learning } \\
\text { Too much repetition } \\
\text { Too little reflection } \\
\text { Staying indoors }\end{array}$ & $\begin{array}{l}\text { Negative or problematic aspects of the } \\
\text { intercultural training. }\end{array}$ & $24 / 03 / 2011$ \\
\hline ICT POS & $\begin{array}{l}\text { Preparation for Jacobs University Bremen } \\
\text { Satisfactory learning } \\
\text { Good experience } \\
\text { Addressed real situations } \\
\text { Interactivity } \\
\text { Socializing } \\
\text { Diverse training group } \\
\text { Fruitful discussions } \\
\text { Nice atmosphere }\end{array}$ & $\begin{array}{l}\text { Positive aspects of the intercultural } \\
\text { training. }\end{array}$ & $24 / 03 / 2011$ \\
\hline ICT SK & $\begin{array}{l}\text { Self-reflection skills } \\
\text { Perspective-taking } \\
\text { Communicating cultural beliefs } \\
\text { Basic communication skills } \\
\text { No skills taught } \\
\text { Hard to teach }\end{array}$ & $\begin{array}{l}\text { Comments on whether and how the } \\
\text { intercultural training helped students to } \\
\text { evolve and strengthen skills to benefit } \\
\text { from the intercultural experience on } \\
\text { campus. }\end{array}$ & $24 / 03 / 2011$ \\
\hline JUB EXP & & $\begin{array}{l}\text { Remarks on general experience at } \\
\text { Jacobs University Bremen. }\end{array}$ & $24 / 03 / 2011$ \\
\hline LM EXP & $\begin{array}{l}\text { Familiar } \\
\text { Difficulties with reading workload } \\
\text { Performance pressure } \\
\text { Easy to adapt } \\
\text { Not influenced by training }\end{array}$ & $\begin{array}{l}\text { Experience of the learning model at } \\
\text { Jacobs University Bremen, e.g. } \\
\text { problems encountered and ease of } \\
\text { adapting to it. }\end{array}$ & $24 / 03 / 2011$ \\
\hline
\end{tabular}




\begin{tabular}{|c|c|c|c|}
\hline & $\begin{array}{l}\text { Training helpful } \\
\text { Unmet expectations (quality of teaching) }\end{array}$ & & \\
\hline METH & $\begin{array}{l}\text { Used } \\
\text { Combination } \\
\text { Preferred } \\
\text { Experiental } \\
\text { Lecture } \\
\text { Combination }\end{array}$ & $\begin{array}{l}\text { Comments on methods used in } \\
\text { intercultural training and methods } \\
\text { preferred by the participant. }\end{array}$ & $24 / 03 / 2011$ \\
\hline METH LEC CON & $\begin{array}{l}\text { Boring } \\
\text { Unnecessary }\end{array}$ & $\begin{array}{l}\text { Negative aspects of lecture-style } \\
\text { method. }\end{array}$ & $24 / 03 / 2011$ \\
\hline METH LEC PRO & Information to work with & Positive aspects of lecture-style method. & $24 / 03 / 2011$ \\
\hline METH EXP CON & & $\begin{array}{l}\text { Negative aspects of experiential-style } \\
\text { method. }\end{array}$ & $24 / 03 / 2011$ \\
\hline METH EXP PRO & $\begin{array}{l}\text { Learning by doing } \\
\text { Foster discussion } \\
\text { Activating } \\
\text { Effective (esp. if purpose unknown) }\end{array}$ & $\begin{array}{l}\text { Positive aspects of experiential-style } \\
\text { method. }\end{array}$ & $24 / 03 / 2011$ \\
\hline P ICT EXPECT & $\begin{array}{l}\text { Redundant due to SUBJ IC EXP } \\
\text { Opportunity for socializing } \\
\text { Receive advice } \\
\text { No specific expectations } \\
\text { Feeling familiar with content } \\
\text { Emphasis on open-mindedness } \\
\text { Hear about different perspectives }\end{array}$ & $\begin{array}{l}\text { Participant's expectations prior to the } \\
\text { intercultural training. }\end{array}$ & $24 / 03 / 2011$ \\
\hline P ICT MOT & $\begin{array}{l}\text { Low } \\
\text { Medium } \\
\text { High } \\
\end{array}$ & $\begin{array}{l}\text { Participant's motivation to attend the } \\
\text { intercultural training. }\end{array}$ & $24 / 03 / 2011$ \\
\hline PTS EXP & $\begin{array}{l}\text { In favor } \\
\text { Against }\end{array}$ & $\begin{array}{l}\text { Participant's general experience of the } \\
\text { peer-trainer scheme. }\end{array}$ & $24 / 03 / 2011$ \\
\hline PTS CON & Insufficient age gap / less authority & Cons of the peer-trainer scheme & $24 / 03 / 2011$ \\
\hline PTS PRO & $\begin{array}{l}\text { Shared experience } \\
\text { Comfortable atmosphere } \\
\text { Higher credibility } \\
\text { Same age } \\
\text { Easier to relate } \\
\text { Applied to Jacobs University setting } \\
\text { Facilitates start at Jacobs University } \\
\text { Interaction with trainers/peers } \\
\end{array}$ & Pros of the peer-trainer scheme & $24 / 03 / 2011$ \\
\hline PTS TRAIN & $\begin{array}{l}\text { Positive } \\
\text { Competent } \\
\text { Approachable } \\
\text { Committed } \\
\text { Nice / open } \\
\text { Reference person } \\
\text { Role model } \\
\text { Negative } \\
\text { Not approachable } \\
\text { Lack of interest } \\
\text { Lack of motivation } \\
\text { Lack of enthusiasm } \\
\text { Difficulty to catch attention }\end{array}$ & $\begin{array}{l}\text { Comments on the trainers themselves, } \\
\text { i.e. any comment that the participant } \\
\text { makes on characteristics of the peer } \\
\text { trainers that conducted his or her } \\
\text { intercultural training. }\end{array}$ & $24 / 03 / 2011$ \\
\hline SUBJ IC EXP & $\begin{array}{l}\text { Limited experience } \\
\text { Some experience } \\
\text { A lot of experience } \\
\end{array}$ & $\begin{array}{l}\text { Subjective degree of previous } \\
\text { intercultural experience of the } \\
\text { participant. }\end{array}$ & $24 / 03 / 2011$ \\
\hline SUGG IMP & $\begin{array}{l}\text { Increase age gap } \\
\text { Integrate culture-specific information } \\
\text { Increase attendance by relocating training } \\
\text { off-campus } \\
\text { Emphasize importance of enthusiasm in } \\
\text { train-the-trainer } \\
\text { Check peer-trainers' schedule } \\
\text { Be careful with stressing mandatory attendance } \\
\text { Longer training }\end{array}$ & $\begin{array}{l}\text { Suggestions for improvement of the } \\
\text { intercultural training offered by the } \\
\text { participant. }\end{array}$ & $24 / 03 / 2011$ \\
\hline
\end{tabular}

\section{(c) $)$ EY}

This work is licensed under a Creative Commons Attribution 3.0 License. 